\title{
Communication
}

\section{Global Medicine, Parasites, and Tasmania}

\author{
John Goldsmid and Silvana Bettiol *(D) \\ School of Medicine, College of Health and Medicine, University of Tasmania, 17 Liverpool Street, \\ Hobart Tasmania 7000, Australia; j.m.goldsmid@utas.edu.au \\ * Correspondence: s.bettiol@utas.edu.au; Tel.: +61-3-6226-4826
}

Received: 6 November 2019; Accepted: 30 December 2019; Published: 1 January 2020

\begin{abstract}
Until the 1970s, infectious disease training in most medical schools was limited to those diseases common in the area of instruction. Those wishing to explore a more globalised curriculum were encouraged to undertake specialist postgraduate training at schools or institutes of tropical medicine. However, the increase in global trade and travel from the 1970s onward led to dramatic changes in the likelihood of returning travellers and new immigrants presenting with tropical infections in temperate regions. Furthermore, population growth and the changing relationships between animals, the environment, and man in agriculture accentuated the importance of a wider understanding of emerging infectious diseases, zoonotic diseases and parasitic infections. These epidemiological facts were not adequately reflected in the medical literature or medical curriculum at the time. The orientation on tropical infections needed specialised attention, including instruction on diagnosis and treatment of such infections. We describe key global health events and how the changing field of global medicine, from the 1970s to early 2000, impacted on medical education and research. We describe the impact of global health changes in the Tasmanian context, a temperate island state of Australia. We retrospectively analysed data of patients diagnosed with parasites and present a list of endemic and non-endemic parasites reported during this period. Finally, we reflect on the new approaches to the changing needs of global health and challenges that medical programmes, learners and educators face today.
\end{abstract}

Keywords: parasitology; zoonoses; tropical medicine; travel medicine; global medicine; Tasmania

\section{Introduction}

In 1964 and based on concerns regarding tropical disease in temperate climates, Dr. Kevin Cahill published a series of articles in The New York State Journal of Medicine. He foresaw that inexpensive boat travel and the shortening transit times by air travel posed a potential infection hazard [1]. By 1974, Woodruff in the preface to his book stated that "Medicine in the tropics is of great importance to all practitioners be they working in temperate or tropical regions" [2]. He had already noted that through travel "even in temperate regions, a significant proportion of the community has now been exposed to disease in tropical and subtropical regions" [2]. What he said then is even more important now with more global connections involving travel and trade, changes in climate, and the environment and human spread into previously uninhabited regions. These factors have led to the possibility of diseases with short incubation periods being brought to countries where they have not been seen before or have been exceedingly rare. Diseases with long and silent incubation periods present the most difficult diagnostic and public health problems. This, has led to growing clinical needs and development of medical practitioners, public health and health professionals with an understanding of these diseases, working at the local, regional, national, and global level. For those teaching and developing medical curricula these diseases present many challenges and have become more complex due to the changing focus of healthcare systems, globalisation, cultural and societal factors, and technology. Despite 
international communications on medical education to address these needs, medical practice remains distinctly different among countries [3].

\section{Time Line of Selected Global Health Events}

Why were the 1970s significant for changes in global medicine? The 1970s was a period when the post-World War II economic expansion and economic boom was drawing to an end and the 1973-1975 recession loomed $[4,5]$. The economic crisis also affected the approach to the control of disease and much of the work in the field reflected the long-term instability and economic difficulty. The range of effective drugs used for human and animal treatment expanded rapidly. However, the treatment was not always in parallel with investigations of how these new drugs should be used to the best effect. Transport of livestock from country to country without an understanding of disease risks and intensive methods of animal management posed hazards to humans [2,6]. Preparing for reduced funding for medical and veterinary services to make further gains in health and wellbeing of humans and animals was not expected. Promoting efficient use of resources was common and a need for evaluation was obvious.

The growing efficiency and reach of modern transport networks led to an emergence of new strains of familiar diseases, as well as completely new diseases. A consequence was the pressure on how to tackle them. It became apparent that there was strong correlation between antibiotic use in the treatment of humans and animals and antibiotic resistance in Gram-negative pathogens. The most prevalent Gram-negative pathogens at this time were Escherichia coli, Salmonella enterica, and Klebsiella pneumoniae [7]. Since then there has been an alarming increase in 'superbugs' and a decline in the development of new antibiotics to cope with the changing situation. Williamson et al. [8] recently highlighted the danger of drug resistance in Candida auris, carbapenemase-producing enterobacteriaceae, Methicillin-resistant Staphylococcus aureus (MRSA) and drug-resistant strains of typhoid and gonorrhoea. Infectious disease specialists note that the world has reached a crisis in the treatment of bacterial infections $[9,10]$.

Between 1965 and 1970, the growth rate of the world's population reached its peak, increasing by $2.1 \%$ per year on average [11]. There was a growing concern of the impact of this population growth on the interaction of humans and the environment and how this would affect tropical diseases. A combination of increased economic activity, human migration, tourism, and encroachment on new environmental niches contributed to the emergence of many zoonotic diseases. The first cases of naturally acquired Plasmodium knowlesi infection [12], the Marburg, Ebola, and Lassa fever viruses [13], and reports of Lyme disease [14] occurred during this period. The earliest reports of a syndrome later identified as HIV/AIDS appeared in the closing year of the 1970s [14].

The 1970s saw the rise of preventive medicine and the self-care movements [15]. In the early part of June 1972, the United Nations Conference on the Human Environment in Stockholm considered the need for "a common outlook and for common principles to inspire and guide the peoples of the world in the preservation and enhancement of the human environment" [16]. Following the Stockholm Declaration, global awareness of environmental issues increased dramatically. In 1992, the second United Nations Conference on Environment and Development (UNCED) in Rio de Janeiro represented a major milestone in the evolution of international environmental law [17]. Today, the Sustainable Goals (SDGs) of the United Nations and the Agenda 2030 reflect the spirit of these principles.

The 1970s initiated great strides in global disease control. A successful example was the Onchocerciasis Control programme, which commenced in 1974 [18]. The serious health and socioeconomic repercussions of onchocerciasis and indications of possible control was a catalyst for a convening of a joint USAID/OCCGE/WHO technical meeting $[18,19]$. The participants included experts in a range of fields including public health, parasitology, epidemiology, entomology, ophthalmology, economics, sociology, and medical geography [18]. The programme brought relief to many communities and with great effort was sustained and continues today, despite difficult circumstances. This programme has become an example of effective public health management 
and one of the largest intercountry undertakings implemented by the World Health Organization (WHO) $[19,20]$.

The decade of the 1970s closed with the successful eradication of smallpox after a 14-year intensive programme [21] and the beginning of new global control programmes. There were specific efforts to increase efficiency and productivity of healthcare systems during the 1980s, including improvement in maternal and child health and a focus on HIV/AIDS, tuberculosis, and malaria in developing countries. In 1986, the Global Programme on AIDS (GPA) was launched by the World Health Organization [22] followed by the Global Polio Eradication Initiative (GPEI) in 1988, which was led jointly by national governments, the WHO, Rotary International, the US Centers for Disease Control and Prevention (CDC), and UNICEF [22,23].

In 1992, the CDC launched the international campaign to eradicate Guinea worm disease and eliminate dracunculiasis [24]. The 1990s welcomed the evolution of large data-driven research and collaboration with the World Bank commissioned to publish the Global Burden of Disease study. Today this collaboration has over 1800 researchers and contributors from 127 countries [25]. Another significant global achievement at this time was the Global Initiative for Traditional Systems of Health created by the Pan American Health Organisation [26]. Today WHO continues to develop proactive policies and action plans to strengthen the role of traditional and complementary medicine (T\&CM) in responding to health needs of populations. Unfortunately, it remains an ongoing challenge for countries trying to implement regulations and national laws for their use [26].

The next factor which influenced human health over these years, and more evident today, was climate change. Changing climate, spread of warmer conditions, and changing rainfall can increase the occurrence of tropical diseases such as malaria, dengue and schistosomiasis and potentially soil transmitted helminthiases by extending their distribution [27]. Changing climate, including pollution, exacerbates public health issues and economic stagnation due to parasitic diseases and these complexities have been highlighted by numerous authors [28-31]. Thus, Han et al. [32] stated that "Health organisations are growing more concerned that climate change will cause zoonotic diseases to become more prolific and widespread" and challenges are more difficult in predicting outbreaks caused by either novel pathogens or known pathogens in novel places.

The continued pressure of economic development has increased the opportunity for pathogens (many previously unknown) with zoonotic potential to cross the species line. The world's population has continued to grow from 3.7 billion in the 1970s to 7.7 billion in 2019 [33] and is projected to increase to 9.7 billion by 2050. Health professionals need to be aware of growth rates and mobility patterns across their regions [34]. Goldsmid [35] noted "that never before in the history of the human race, have so many people been able to travel so far so quickly and so cheaply" - and this is even truer today!

A review of the literature estimates the number of people that acquire an infectious disease during or as a result of travel ranges from $6 \%$ to $87 \%$ [36]. These figures may change as current projections suggest the annual number of international travellers will reach 1.8 billion by 2030 [36]. International tourism in Australia for example has grown significantly in the past two decades. The number of short-term overseas visitor arrivals rose from 2.5 million in 1992 to 9.3 million in 2018-2019, the highest year on record [37]. Outbound international trips have nearly doubled in the past decade. The scale and speed of contemporary international travel means an increasing possibility of travellers being exposed to unfamiliar infections.

Accurate data of the proportion of people who acquire an illness overseas are difficult to calculate as exposure is dependent on the destination, baseline medical history, and also planned activities [38]. In recent years research in travel medicine has grown. There are tropical medicine surveillance networks, such as the GeoSentinel surveillance network composed of International Society of Travel Medicine (ISTM) travel and tropical medicine clinics that collect post-travel illness surveillance data [39,40], but there are limitations. Therefore, physicians need to be familiar with destination-specific disease risks, travel and routine vaccines, and chemoprophylaxis regimens. Reviews of current evidence in the discipline are readily available [41]. 
A major area of medical relevance in the fields of tropical travel, migrant and refugee medicine is parasitic infections. The estimates of the prevalence and incidence of neglected tropical diseases and malaria from the Global Burden of Disease Study 2017 [42] are thought provoking. While some parasitic diseases such as falciparum malaria and human African trypanosomiasis (East African variety) cause acute infections with a high mortality, most parasitic infections are chronic infections. An example is cysticercosis [43-45] which is increasingly recorded in non-endemic regions around the world [43].

\section{Historical Overview of Tasmania and Parasites of Medical Importance}

Historically, nearly all of the infectious diseases seen in Australia, and especially Tasmania, have been imported since European/Asian settlement of the continent [46] and many of the commoner infections then became endemic as the population grew. Tasmania has a long history associated with imported infections, starting with the first settlement by Europeans (especially the convicts) and continuing from there. Tasmania provides a strong case against a parochial approach to medicine especially in the changing world today. It is a good model for study in relation to imported infections and the relevance of travel in this regard. The reasons are:

(1) Tasmania is a small relatively isolated island, protected by surrounding water.

(2) Tasmania has a temperate climate with a high standard of living and with good health services.

(3) Tasmania has a small resident population and consequently has fewer overseas travellers or returning travellers.

(4) Tasmania has few direct overseas connections and fewer overseas visitors than the more populous and easily accessible mainland states of Australia.

The question thus arises-How big a range of endemic and 'exotic' imported infections has been diagnosed in humans in Tasmania over recent years? A retrospective analysis of recorded cases was completed and is reported below. Helminth infections are summarised in Table 1 and other key parasites diagnosed in Tasmania in Table 2.

Table 1. Helminth infections diagnosed in Tasmania:

\begin{tabular}{|c|c|c|}
\hline Trematodes: & Cestodes: & Nematodes: \\
\hline Echinostoma sp. ** & Echinococcus granulosis *** & Ancylostoma duodenale ** \\
\hline Fasciola hepatica ** & Hymenolepis nana *** & Ascaris lumbricoides *** \\
\hline Opisthorchis viverrni ${ }^{* *}$ & Taenia saginata ** & Ascaris suum * \\
\hline \multirow{12}{*}{$\begin{array}{l}\text { Schistosoma haematobium } \\
\text { Schistosoma mansoni } \\
\text { ** }\end{array}$} & Taenia solium (cysticercosis) ** & Cutaneous larva migrans ** \\
\hline & & Enterobius vermicularis * \\
\hline & & Eucoleus aerophilus (Capilalria aerophila)* \\
\hline & & Haycocknema perplexum ${ }^{* *}$ \\
\hline & & Loa loa $* *$ \\
\hline & & Necator americanus ** \\
\hline & & Strongyloides stercoralis ** \\
\hline & & Toxocara spp. * \\
\hline & & Trichinella pseudospiralis * \\
\hline & & Trichuris trichiura *** \\
\hline & & Trichostrongylus spp. ${ }^{* *}$ \\
\hline & & $\begin{array}{l}\text { Wuchereria bancrofti lymphatic filariasis and tropical } \\
\text { pulmonary eosinophilia ** }\end{array}$ \\
\hline
\end{tabular}

Key to coding: Endemic cases *, Imported cases ${ }^{* *}$, Endemic and imported cases ${ }^{* * *}$.

In the mid-20th Century, Tasmania experienced one of the highest rates of human hydatid disease in the world $[47,48]$. Echinococcus granulosus, which causes cystic echinococcosis is the only member of the genus Echinococcus to be found in Australia. It was introduced during the early period of European settlement and described in domestic animals before 1840 [49]. In the early 1960s, the state government commenced a hydatid control programme across Tasmania aimed at stopping transmission of hydatid disease to humans. By 1996, Tasmania was declared provisionally free of hydatids in dogs and livestock [50]. 
Table 2. Protozoa and Arthropoda diagnosed in Tasmania.

\begin{tabular}{|c|c|c|}
\hline Protozoa & Arthropoda-Insecta: & Arthropoda-Acarina \\
\hline 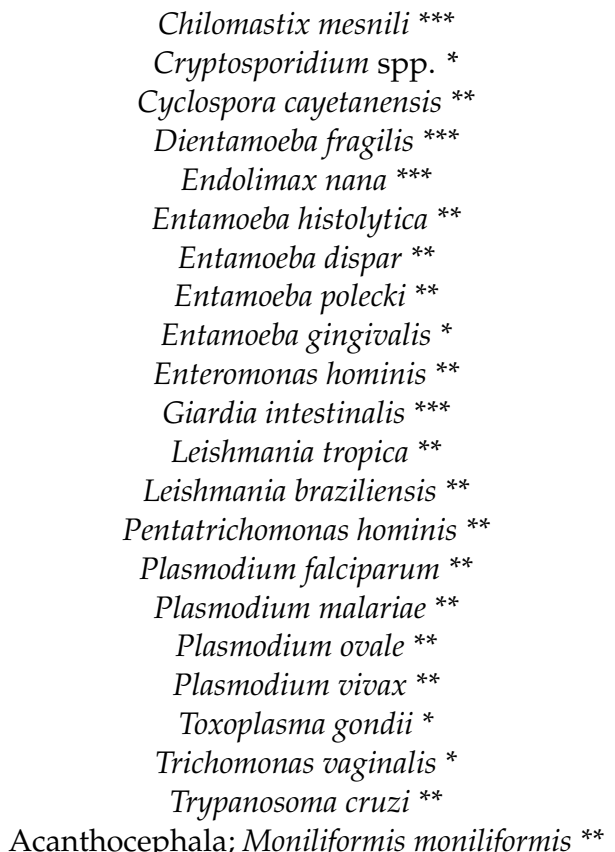 & $\begin{array}{l}\text { Cordylobia anthropophaga ** } \\
\text { Dermatobia hominis ** } \\
\text { Tunga penetrans } \\
\text { ** } \\
\text { Pediculus humanus capitis * } \\
\text { Pediculus humanus corporis * }\end{array}$ & $\begin{array}{l}\text { Sarcoptes scabiei } \\
\text { Ixodid ticks * }\end{array}$ \\
\hline
\end{tabular}

Key to coding: Endemic cases *, Imported cases ${ }^{* *}$, Endemic and imported cases ${ }^{* * *}$.

Of the helminth cases, the Tasmanian cases of Trichinella pseudospiralis and Haycocknema perplexum are the most intriguing as they were the first human cases of these worms ever reported [51-53]. It was first described from a patient in Tasmania by Spratt et al. [54]. Subsequent cases diagnosed had all lived in or visited Tasmania. Many had histories of contact with native animals or eating bush meat and it was thought that the infection was an endemic zoonosis from Tasmania $[55,56]$. A subsequent case from tropical North Queensland had no contact with Tasmania and a re-evaluation of all the recorded cases showed that they all had contact with the tropical north of Australia. The result that the condition was considered to be endemic there and being redescribed the disease as "tropical parasitic myositis" [57]. However, the most recently reported case from Tasmania had no travel history, except to Melbourne in southern Victoria [56], confirming that $H$. perplexum is indeed endemic to Tasmania. The natural reservoir of $H$. perplexum has not been found to date and the mode of transmission to humans is also unknown. Human T. pseudospiralis has subsequently been described from humans in France and Thailand but the enigma of $H$. perplexum continues.

Vaccine development and application to control zoonotic diseases in food animals, companion animals, and wildlife have made a significant impact in reducing the incidence of zoonotic diseases in people [58]. At the same time, biosecurity in Australia has played a critical role in maintaining its reputation as a country free of severe pests and diseases. The Commonwealth Quarantine Service started operations in 1908 and today Biosecurity Australia monitors plant and animal health across Australia. While most infections in Australia have been controlled it has led to over-confidence regarding their importance (or even existence) today. Unfortunately, while ubiquitous protozoan species have been reported in wildlife across Australia [51-61] the life cycles, ecology, and general biology of most parasites of wildlife in Australia are poorly understood. Much of the work to date has been opportunistic with unreliable funding opportunities, but with modern methods and 'omic' technology [62] offering an avenue for major advances in the field, there is potential for renewed support and interest.

An analysis of imported malaria in Tasmania (Table 2) was initially reported over a 5-year period from 1987 to 1992 and subsequently extended to cover 1987-1994 [63]. During this period, 
80 cases of malaria were diagnosed covering three species: Plasmodium vivax (81.2\%) followed by Plasmodium falciparum (16.2\%), and Plasmodium malariae (2.6\%). Cases came from Asia, Southeast Asia, Africa, Papua New Guinea (PNG), Vanuatu, the Solomons, and one case acquired in Thursday Island (administratively a part of Australia and an area considered free from malaria due to control measures). The cases were diagnosed from across the State, including two from Antarctica-a region administered from Tasmania (Goldsmid, pers. Comm. 2019). These cases continued to influence curriculum development in tropical and travel disease in the undergraduate medical school. Expanding medical training in tropical disease for Tasmanian medical practitioners was highlighted by one of these malaria cases when originally misdiagnosed (as influenza). The general practitioner (GP) involved explained the patient presented during an influenza epidemic in his area and, as he ruefully admitted, he did not ask the patient about any travel history. Luckily it was a case of benign tertian malaria (Plasmodium vivax) - the error could have been tragic if it had been a case of P. falciparum malaria

New treatments are, however, being developed, albeit rather slowly and an example of this is the treatment of Plasmodium vivax relapses with tafenoquine (kozenis) and artesunate for severe falciparum malaria [64]. The recent and rapid clinical development of vaccines is making considerable impact world-wide. The vaccine against Plasmodium falciparum, RTS,S/AS01 (RTS,S) is a promising vaccine candidate for malaria currently part of a landmark pilot program in three African countries, and is available to children up to 2 years of age [65]. Another recent example is the vesicular stomatitis virus-based Ebola virus vaccine (VSV-EBOV) currently in a clinical trial [66]. It is viewed as a potential tool for both current and future Ebola outbreaks.

Infectious diseases and pandemic preparedness remain a priority on the world agenda, despite the shift in focus to non-communicable diseases. The Sustainable Development Goals (SDGs) provide a framework for a holistic answer to the ensuing challenges and respond to these complex interactions but collaboration between research disciplines is essential. A recent paper by committee members of the World Heath Summit supports the view that leading institutions and organisations are responsible to promote transdisciplinary, cross-sectoral, science-based and concerted efforts for more efficient and equitable ways to advance health on a global scale [67].

\section{Conclusions}

Changing attitudes over the course of several decades mean medicine has slowly been considered in global terms rather than discrete specialties. The changing patterns in disease suggest a need for new conceptual models in medical training and medical education. There have been many attempts to frame the impact of globalisation on health [68] based on international health, public health, and tropical medicine [68-70]. During the period of our work in medical curriculum development and medical microbiology teaching the commoner categories included: tropical medicine, travel medicine, migrant medicine, and traditional and complementary medicine. All of these specialties, to varying degrees, can be encompassed under the broad title of 'Global Medicine'. This has coincided with attempts to integrate modern science into the medical curricula and equip health professionals to meet the future health needs of populations.

The One Health concept recognises the health connections between humans, animals, and their shared environments [71]. Its approach has been endorsed by a number of medical and public health organisations and medical schools around the world [71]. The concept of planetary health, which became part of the fabric of integrative medicine in the 1990s, has since become a concept that has penetrated mainstream academic and medical discourse. In fact, it provides a new multidisciplinary approach to understanding the interconnections between environmental and human health. It is often viewed as a response to existing fields of public health, environmental health, Ecohealth, One Health, and international health [72].

The impressive range of infections currently seen and potentially emergent emphasises what Bradley [73] warned the medical profession over 30 years ago, that a holistic view is one all specialties must embrace. Our work in medical education and our past experiences are still valid today. Tropical 
diseases are not confined to the tropics. They are being increasingly encountered in non-tropical areas and thus must be considered a global problem.

Author Contributions: J.G. and S.B. both participated substantially in the writing and editing of this manuscript. All authors have read and agreed to the published version of the manuscript.

Funding: This research received no external funding.

Acknowledgments: We thank Richard Bradbury and ACTM for the invitation and opportunity to contribute to this special issue. Thanks to Gregory Woods and Associate Bruce Lyons for reviewing this work.

Conflicts of Interest: The authors declare no conflicts of interest.

\section{References}

1. Cahill, K.M. Tropical Diseases in Temperate Climates. Lippincott: Philadelphia, PA, USA; Montreal, QC, Canada, 1964; pp. 1-216.

2. Woodruff, A.W. Medicine in the Tropics; Churchill Livingstone: Edinburgh/London, UK, 1974; ISBN 0443009562.

3. O'Brien, B.C.; Forrest, K.; Wijnen-Meijer, M.; ten Cate, O. A Global View of Structures and Trends in Medical Education. In Understanding Medical Education: Evidence, Theory, and Practice, 3rd ed.; Swanwick, T., Forrest, K., O'Brien, B.C., Eds.; Wiley-Blackwell: Hoboken, NJ, USA, 2018; pp. 7-22. Available online: https://doi.org/10.1002/9781119373780 (accessed on 27 November 2019).

4. Zarnowitz, V.; Moore, G.H. The recession and recovery of 1973-1976. In Explorations in Economic Research; NBER: Cambridge, MA, USA, 1977; Volume 4, pp. 1-87. Available online: https://apps.who.int/gb/ebwha/ pdf_files/EB144/B144_22-en.pdf (accessed on 2 October 2019).

5. Marglin, S.A.; Schor, J.B. The Golden Age of Capitalism: Reinterpreting the Postwar Experience; Oxford University Press: Oxford, UK, 1991; ISBN 9780198287414.

6. Gubler, D.J. Vector-borne diseases. Rev. Sci. Tech. 2009, 28, 583-588. [CrossRef]

7. Davies, J.; Davies, D. Origins and evolution of antibiotic resistance. Microbiol. Mol. Biol. Rev. 2010, 74, 417-433. [CrossRef] [PubMed]

8. Williamson, D.A.; Howden, B.P.; Paterson, D.L. The risk of resistance: What are the major antimicrobial resistance threats facing Australia? Med. J. Aust. 2019, 211, 103-105. [CrossRef]

9. Hall, W. Superbugs: An Arms Race Against Bacteria; Harvard University Press: Cambridge, MA, USA, 2018; pp. 1-256. ISBN 9780674975989.

10. McCarthy, M. Superbugs: The Race to Stop an Epidemic; Penguin Random House Audio: New York, NY, USA, 2019; p. 304. ISBN 978-0735217508.

11. Roser, M.; Ritchie, H.; Ortiz-Ospina, E. World Population Growth. Available online: https://ourworldindata. org/world-population-growth (accessed on 27 November 2019).

12. Singh, B.; Daneshvar, C. Human infections and detection of Plasmodium knowlesi. Clin. Microbiol. Rev. 2013, 26, 165-184. [CrossRef]

13. Seah, S.K. Lassa, Marburg and Ebola: Newly described African fevers. Can. Med. Assoc. J. 1978, 118, 347-348.

14. Ferguson, R. Emerging infectious diseases-1970s. J. Community Hosp. Intern. Med. Perspect. 2016, 6, 32662. [CrossRef]

15. Prescott, S.L.; Logan, A.C.; Katz, D.L. Preventive Medicine for Person, Place, and Planet: Revisiting the Concept of High-Level Wellness in the Planetary Health Paradigm. Int. J. Environ. Res. Public Health 2019, 16, 238. [CrossRef] [PubMed]

16. UN General Assembly. In Proceedings of the United Nations Conference on the Human Environment, Stockholm, Sweden, 15 December 1972; A/RES/2994. Available online: https:/www.refworld.org/docid/ 3b00f1c840.html (accessed on 12 November 2019).

17. United Nations. Transforming Our World: The 2030 Agenda for Sustainable Development. General Assembly 70 Session. 2015. Available online: https:/www.unfpa.org/sites/default/files/resource-pdf/Resolution_A_ RES_70_1_EN.pdf (accessed on 10 August 2019).

18. World Health Organization. Onchocerciasis Control in the Volta River Basin Area: Report of the Mission for Preparatory Assistance to the Governments of Dahomey, Ghana, Ivory Coast, Mali, Niger, Togo and Upper Volta; (No. OCP/73.1); WHO: Geneva, Switzerland, 1973; Available online: https://apps.who.int/iris/handle/10665/326129 (accessed on 10 August 2019). 
19. Samba, E.M.; World Health Organization. The Onchocerciasis Control Programme in West Africa: An Example of Effective Public Health Management/Ebrahim M. Samba; WHO: Geneva, Switzerland, 1994; Available online: https://apps.who.int/iris/handle/10665/39261 (accessed on 10 August 2019).

20. Thylefors, B. Onchocerciasis: Impact of interventions. Community Eye Health 2001, 14, 17-19.

21. World Health Organization. The Smallpox Eradication Programme-SEP (1966-1980). 2010. Available online: https://www.who.int/features/2010/smallpox/en/ (accessed on 31 October 2019).

22. Lisk, F. The rise and fall of the WHO's Global Program on AIDS (GPA). In Global Institutions and the HIV/AIDS Epidemic: Responding to an International Crisis; Routledge: London, UK; New York, NY, USA, 2009; pp. 15-27.

23. Henderson, R.H. The World Health Organization's Plan of Action for Global Eradication of Poliomyelitis by the Year 2000. Ann. N. Y. Acad. Sci. 1989, 569, 69-85. [CrossRef]

24. Centers for Disease Control and Prevention. Parasites—Guinea Worm-Eradication Program. 2019. Available online: https://www.cdc.gov/parasites/guineaworm/gwep.html (accessed on 31 October 2019).

25. Das, P. The story of GBD 2010: A “super human” effort. Lancet 2012, 380, 2067-2070. [CrossRef]

26. World Health Organization. WHO Global Report on Traditional and Complementary Medicine 2019; World Health Organization: Geneva, Switzerland, 2019; Available online: https://apps.who.int/iris/handle/10665/312342 (accessed on 10 December 2019).

27. Weaver, H.J.; Hawdon, J.M.; Hoberg, E.P. Soil-transmitted helminthiases: Implications of climate change and human behavior. Trends Parasitol. 2010, 26, 574-581. [CrossRef] [PubMed]

28. Andreae, M.O.; Rosenfeld, D.; Artaxo, P.; Costa, A.A.; Frank, G.P.; Longo, K.M.; Silva-Dias, M.A. Smoking rain clouds over the Amazon. Science 2004, 303, 1309-1311. [CrossRef] [PubMed]

29. Patz, J.A.; Olson, S.H. Climate change and health: Global to local influences on disease risk. Ann. Trop. Med. Parasitol. 2006, 100, 535-539. [CrossRef] [PubMed]

30. Patz, J.A.; Gibbs, H.K.; Foley, J.A.; Rogers, J.V.; Smith, K.R. Climate change and global health: Quantifying a growing ethical crisis. EcoHealth 2007, 4, 397-405. [CrossRef]

31. Short, E.E.; Caminade, C.; Thomas, B.N. Climate change contribution to the emergence or re-emergence of parasitic diseases. Infect. Dis. (Auckl.) 2017, 10, 1-7. [CrossRef]

32. Han, B.A.; Kramer, A.M.; Drake, J.M. Global patterns of zoonotic disease in mammals. Trends Parasitol. 2016, 32, 565-577. [CrossRef]

33. United Nations Department of Economic and Social Affairs, Population Division, World Population Prospects 2019. Highlights (ST/ESA/SER.A/423). Available online: https://population.un.org/wpp/Publications/Files/ WPP2019_Highlights.pdf (accessed on 10 August 2019).

34. Garske, T.; Yu, H.; Peng, Z.; Ye, M.; Zhou, H.; Cheng, X.; Wu, J.; Ferguson, N. Travel patterns in China. PLoS ONE 2011, 6, e16364. [CrossRef]

35. Goldsmid, J.M. The Travel Bug; Occ. Paper No 17; University of Tasmania: Hobart, Australia, 1979.

36. Angelo, K.M.; Kozarsky, P.E.; Ryan, E.T.; Chen, L.H.; Sotir, M.J. What proportion of international travellers acquire a travel-related illness? A review of the literature. J. Travel Med. 2017, 24. [CrossRef]

37. Australian Bureau of Statistics. Overseas Arrivals and Departures, Australia, July 2019 cat. no. 3401.0. Available online: https:/www.abs.gov.au/ausstats/abs@.nsf/featurearticlesbyCatalogue/ A5438F2F06B39A8FCA258493001E8822?OpenDocument (accessed on 5 September 2019).

38. Maloney, S.A.; Weinberg, M. Prevention of infectious diseases among international pediatric travelers: Considerations for clinicians. Semin. Pediatr. Infect. Dis. 2004, 15, 137-149. [CrossRef]

39. Leder, K.; Torresi, J.; Libman, M.D.; Cramer, J.P.; Castelli, F.; Schlagenhauf, P.; Wilder-Smith, A.; Wilson, M.E.; Keystone, J.S.; Schwartz, E.; et al. GeoSentinel surveillance of illness in returned travelers, 2007-2011. Ann. Intern. Med. 2013, 158, 456-468. [CrossRef]

40. Harvey, K.; Esposito, D.H.; Han, P.; Kozarsky, P.; Freedman, D.O.; Plier, D.A.; Sotir, M.J. Surveillance for travel-related disease-GeoSentinel surveillance system, United States, 1997-2011. MMWR Surveill. Summ. 2013, 62, 1-23.

41. Leung, D.T.; LaRocque, R.C.; Ryan, E.T. Travel Medicine. Ann. Intern. Med. 2018, 168, ITC1-ITC16. [CrossRef]

42. James, S.L.; Abate, D.; Abate, K.H.; Abay, S.M.; Abbafati, C.; Abbasi, N.; Abbastabar, H.; Abd-Allah, F.; Abdela, J.; Abdelalim, A.; et al. Global, regional, and national incidence, prevalence, and years lived with disability for 354 diseases and injuries for 195 countries and territories, 1990-2017: A systematic analysis for the Global Burden of Disease Study 2017. Lancet 2018, 392, 1789-1858. [CrossRef] 
43. Garcia, H.H.; Nash, T.E.; Del Brutto, O.H. Clinical symptoms, diagnosis, and treatment of neurocysticercosis. Lancet Neurol. 2014, 13, 1202-1215. [CrossRef]

44. Roman, G.; Sotelo, J.; Del Brutto, O.; Flisser, A.; Dumas, M.; Wadia, N.; Botero, D.; Cruz, M.; Garcia, H.; De Bittencourt, P.R.M.; et al. A proposal to declare neurocysticercosis an international reportable disease. Bull. World Health Organ. 2000, 78, 399-406.

45. Hunter, E.; Cliff, M.; Armstrong, M.; Manji, H.; Jäger, H.R.; Chiodini, P.; Brown, M. Active neurocysticercosis at the Hospital for Tropical Diseases, London: A clinical case series. Trans. R. Soc. Trop. Med. Hyg. 2018, 112, 326-334. [CrossRef] [PubMed]

46. Goldsmid, J. The Deadly Legacy: Australian History and Transmissible Disease; (No. 3); New South Wales University Press: Kensington, Australia, 1988; p. 115.

47. Beard, T.C. Hydatid control: A problem in health education. Med. J. Aust. 1969, 2, 456-459. [CrossRef]

48. Beard, T.C.; Bramble, A.J.; Middleton, M.J. Eradication in Our Lifetime: A Log Book of the Tasmanian Hydatid Control Programs, 1962-1996; Department of Primary Industries, Water and Environment: Hobart, Tasmania, Australia, 2001.

49. Gemmell, M.A. Australasian contributions to an understanding of the epidemiology and control of hydatid disease caused by Echinococcus granulosus_Past, present and future. Int. J. Parasitol. 1990, 20, 431-456. [CrossRef]

50. Jenkins, D.J. Echinococcus granulosus in Australia, widespread and doing well! Parasitol. Int. 2006, 55, S203-S206. [CrossRef] [PubMed]

51. Andrews, J.R.; Ainsworth, R.; Abernethy, D. Trichinella pseudospiralis in humans: Description of a case and its treatment. Trans. R. Soc. Trop. Med. Hyg. 1994, 88, 200-203. [CrossRef]

52. Andrews, J.R.; Ainsworth, R.; Pozio, E. Nematodes in human muscle. Parasitol. Today 1997, 12, 488-489. [CrossRef]

53. Andrews, J.R.H.; Bandi, C.; Pozio, E.; Morales, M.G.; Ainsworth, R.; Abernethy, D. Identification of Trichinella pseudospiralis from a human case using random amplified polymorphic DNA. Am. J. Trop. Med. Hyg. 1995, 53, 185-188. [CrossRef] [PubMed]

54. Spratt, D.M.; Beveridge, I.; Andrews, J.R.; Dennett, X. Haycocknema perplexum ng, n. sp. (Nematoda: Robertdollfusidae): An intramyofibre parasite in man. Syst. Parasitol. 1999, 43, 123-131. [CrossRef]

55. Vos, L.J.; Robertson, T.; Binotto, E. Haycocknema perplexum: An emerging cause of parasitic myositis in Australia. Commun. Dis. Intell. Q. Rep. 2016, 40, E496-E499. [PubMed]

56. Koehler, A.V.; Leung, P.; McEwan, B.; Gasser, R.B. Using PCR-Based Sequencing to Diagnose Haycocknema perplexum Infection in Human Myositis Case, Australia. Emerg. Infect. Dis. 2018, 24, 2368-2370. [CrossRef] [PubMed]

57. Basuroy, R.; Pennisi, R.; Robertson, T.; Norton, R.; Stokes, J.; Reimers, J.; Archer, J. Parasitic myositis in tropical Australia. Med. J. Aust. 2008, 188, 254-256. [PubMed]

58. Roth, J.A.; Galyon, J.; Stumbaugh, A. Causes and consequences of emerging and exotic diseases of animals: Role of the veterinarian. Vet. Microbiol. Prev. Med. Publ. 2010, 91, 10-17. Available online: https://ib.dr.iastate.edu/vmpm_pubs/91/ (accessed on 27 November 2019).

59. Spratt, D.M.; Beveridge, I. Wildlife parasitology in Australia: Past, present and future. Aust. J. Zool. 2019, 66, 286-305.

60. Kettlewell, J.S.; Bettiol, S.S.; Davies, N.; Milstein, T.; Goldsmid, J.M. Epidemiology of giardiasis in Tasmania: A potential risk to residents and visitors. J. Travel Med. 1998, 5, 127-130. [CrossRef]

61. Bettiol, S.S.; Kettlewell, J.S.; Davies, N.J.; Goldsmid, J.M. Giardiasis in native marsupials of Tasmania. J. Wildl. Dis. 1997, 33, 352-354. [CrossRef]

62. Kille, P.; Field, D.; Bailey, B.; Blaxter, M.; Morrison, N.; Snape, J.; Turner, S.; Viant, M. NERC Environmental 'Omics Strategy'. Available online: https://nerc.ukri.org/research/funded/programmes/omics/neomics-report/ (accessed on 5 September 2019).

63. Goldsmid, J.M.; Sullivan, P. Malaria in Tasmania 1987-1992. J. Travel Med. 1994, 1, 55-56. [CrossRef] [PubMed]

64. Ashley, E.A.; Phyo, A.P. Drugs in development for malaria. Drugs 2018, 78, 861-879. [CrossRef] [PubMed]

65. Laurens, M.B. RTS, S/AS01 vaccine (Mosquirix ${ }^{\mathrm{TM}}$ ): An overview. Hum. Vaccin. Immunother. 2019, $22,1-10$. [CrossRef] [PubMed] 
66. Suder, E.; Furuyama, W.; Feldmann, H.; Marzi, A.; de Wit, E. The vesicular stomatitis virus-based Ebola virus vaccine: From concept to clinical trials. Hum. Vaccin. Immunother. 2018, 14, 2107-2113. [CrossRef] [PubMed]

67. Ganten, D.; Silva, J.G.; Regateiro, F.; Jafarian, A.; Boisjoly, H.; Flahault, A.; Canny, B.; Auler, J.O., Jr.; Kickbusch, J.; Heldmann, J.; et al. Science Has to Take Responsibility 10 Years World Health Summit-The Road to Better Health for All. Front. Public Health 2018, 6, 314. [CrossRef]

68. Havemann, M.; Bösner, S. Global Health as "umbrella term"—A qualitative study among Global Health teachers in German medical education. Glob. Health 2018, 14, 32. [CrossRef]

69. Banta, J.E. From international health to global health. J. Community Health 2001, 26, 73-76. [CrossRef]

70. Jain, S.C. Global health: Emerging frontier of international health. Asia Pac. J. Public Health 1991, 5, 112-114. [CrossRef]

71. Rabinowitz, P.M.; Natterson-Horowitz, B.J.; Kahn, L.H.; Kock, R.; Pappaioanou, M. Incorporating one health into medical education. BMC Med. Educ. 2017, 17, 45. [CrossRef]

72. Whitmee, S.; Haines, A.; Beyrer, C.; Boltz, F.; Capon, A.G.; de Souza, B.F.; Ezeh, A.; Frumkin, H.; Gong, P.; Head, P.; et al. Safeguarding human health in the Anthropocene epoch: Report of the Rockefeller Foundation-Lancet Commission on planetary health. Lancet 2015, 386, 1973-2028. [CrossRef]

73. Bradley, D.J. The scope of Travel Medicine: An introduction to the Conference on International Travel Medicine. In Travel Medicine, Proceedings of the First Conference on International Travel Medicine, Zürich, Switzerland, 5-8 April 1988; Steffen, R., Lobel, H.O., Haworth, J., Bradley, D.J., Eds.; Springer: Berlin/Heidelberg, Germany, 1989; pp. 1-596.

(C) 2020 by the authors. Licensee MDPI, Basel, Switzerland. This article is an open access article distributed under the terms and conditions of the Creative Commons Attribution (CC BY) license (http://creativecommons.org/licenses/by/4.0/). 